\title{
Uptake and Accumulation of Cadmium and Relative Gene Expression in Roots of Cd-resistant Salix matsudana Koidz
}

\author{
Hangfeng Wu, Jiayue Wang, Binbin Li, Yangjie Ou, \\ Wusheng Jiang, Donghua Liu, Jinhua Zou* \\ Tianjin Key Laboratory of Animal and Plant Resistance, College of Life Sciences, Tianjin Normal University, \\ Tianjin 300387, People's Republic of China
}

Received: 24 May 2016

Accepted: 05 July 2016

\begin{abstract}
Salix matsudana is thought to be an ideal woody plant for use in phytoremediation programs in China. This study deals with the characterization of early responses to $\mathrm{Cd}$ in accumulation and its effects on other metals, and relative gene expression in roots exposed to $50 \mu \mathrm{M}$ of $\mathrm{Cd}$ for 1 to 24 hours. The $\mathrm{Cd}$ content in roots exposed to $\mathrm{Cd}$ for $1,3,6,12$, and 24 hours of treatment was approximately $280,587,605$, 622, and $795 \mu \mathrm{g} / \mathrm{g}$ DW, respectively. After 24 hours, Cd stress caused a decrease of iron (Fe) (34.1\%), manganese $(\mathrm{Mn})(60.1 \%)$, zinc $(\mathrm{Zn})(40.7 \%)$ and calcium $(\mathrm{Ca})(26.5 \%)$. After 24 hours of exposure, the relative expression of IRT1 was 6.7 times that of control treatment $(P<0.05)$. A $160.8 \%$ increase was detected for the relative expression of NRAMP1 after exposure to Cd treatment for one hour. After three hours of stress, the expression of ZIP1 was 10 times that of control $(P<0.05)$. The tolerance of plants to Cd involves gene expression, protein modification, and alterations in the coordination of major and secondary metabolites, which is a complex physiological and biochemical process.
\end{abstract}

Keywords: cadmium (Cd), elements, gene expression, Salix matsudana Koidz, uptake and accumulation

\section{Introduction}

With the rapid development of modern agriculture, industry, and anthropogenic activities, trace concentrations of cadmium $(\mathrm{Cd})$ in the environment tend to accumulate to toxic concentrations. Cd is used in mining, electroplating, iron and steel manufacturing, and the battery production process, and is often discharged into the environment [1]. $\mathrm{Cd}$ is considered the most harmful and common pollutants in agricultural soils and other plant environments [2-

*e-mail: zjhmon@163.com
3]. In China, nearly 5 million acres of arable land have been contaminated by heavy metals [4]. According to reports, $\mathrm{Cd}$ concentrations in soil near smelters in China is extremely high - up to $11.2-197.3 \mathrm{mg} / \mathrm{kg}$ [5-6]. Although $\mathrm{Cd}$ is a non-essential element of crops, it is easily absorbed by plants growing in Cd-polluted soils.

Several genes have been demonstrated to be involved in metal accumulation and tolerance, detoxification, vacuolisation, translocation (to shoots), and balance of nutrients in plant roots [7-10]. Recent studies have indicated that Zn-regulated transporter-like proteins and Fe-regulated transporter-like proteins (ZIPs) are involved 
in the hyperaccumulator Thlaspi caerulescens [11], the natural resistance-associated macrophage protein (NRAMP), the cation diffusion facilitator protein (CDF) family [12], and the heavy metal-transporting P1B-type ATPase (HMA) [13]. Cd is most likely crossing the plasma membrane via members of the ZIP transporter family (ZRT-IRT like protein; zinc-regulated transporter, iron-regulated transporter protein) (Guerinot, 2000). IRT1 (iron-regulated transporter protein) is not only the main root transporter of Fe taken from the soil, but is also the main entry route of Cd [14]. Besides IRT1, ZIP1 (zincregulated protein) has been shown to transport $\mathrm{Cd}$ in plants [15-16].

The NRAMP family metal transporters function as $\mathrm{Fe}$ transporters. NRAMP5 is involved in the transportation of $\mathrm{Cd}$ from the soil to root cells and is also a transporter of Mn [12]. NRAMP1 is localized in the plasma membrane of root cells, functioning as a high-affinity transporter for Mn uptake [17]. AtNRAMP1 expression induced by $\mathrm{Fe}$ deficiency in roots is thought to control $\mathrm{Fe}$ homeostasis in plants [18-19] and may be involved in an enhanced influx of Cd into the cells, causing Cd toxicity [20-21]. HMA3 may be involved in the detoxification of metals by chelating $\mathrm{Cd}$ into the vacuole [22]. Plant roots are well known as an organ sensitive to environmental stress [23]. Gene expression differences can reveal metal absorption, accumulation, and tolerance traits. Therefore, monitoring differentially relative expression levels of genes under $\mathrm{Cd}$ stress is very useful for understanding $\mathrm{Cd}$ hyperaccumulation/tolerance mechanisms.

The objectives of the present study were to investigate uptake and accumulation of $\mathrm{Cd}$ and relative gene expression (IRT1, NRAMP1, and ZIP1 genes) in roots of Cd-resistant $S$. matsudana exposed to $50 \mu \mathrm{M} \mathrm{Cd}$ over a short period of treatment $(1,3,6,12$, and 24 hours). The identified physiological and molecular data provide novel insight into $\mathrm{Cd}$ tolerance in woody plants, which can in turn play an important role in phytoremediation investigations.

\section{Materials and Methods}

\section{Plant Material and Growth Conditions}

Woody cuttings (25 cm long) from one year-old shoots of $S$. matsudana were collected and fully rinsed with distilled water before starting the experiments. After dipping in distilled water at room temperature, 10-day-old healthy plants were transferred to half-strength Hoagland nutrient solution and grown for a week. In the previous investigation, we treated $S$. matsudana with a different concentration of $\mathrm{Cd}$ and found that $50 \mu \mathrm{M} \mathrm{Cd}$ is only just a little influence on phenotype and growth. Thus, we chose this concentration in the present investigation. They were spiked with $50 \mu \mathrm{M}$ Cd for 1, 3, 6, 12, and $24 \mathrm{~h}$. Cadmium was provided as cadmium chloride $\left(\mathrm{CdCl}_{2}\right)$. The nutrient solution consisted of $5 \mathrm{mM} \mathrm{Ca}\left(\mathrm{NO}_{3}\right)_{2}, 5 \mathrm{mM} \mathrm{KNO}$, $1 \mathrm{mM} \mathrm{KH} \mathrm{PO}_{4}, 1 \mathrm{mM} \mathrm{MgSO}, 50 \mu \mathrm{M} \mathrm{H}_{3} \mathrm{BO}_{3}, 10 \mu \mathrm{M}$
FeEDTA, $4.5 \mu \mathrm{M} \mathrm{MnCl}_{2}, 3.8 \mu \mathrm{M} \mathrm{ZnSO}_{4}, 0.3 \mu \mathrm{M} \mathrm{CuSO}_{4}$, and $0.1 \mu \mathrm{M}\left(\mathrm{NH}_{4}\right)_{6} \mathrm{Mo}_{7} \mathrm{O}_{24}$ adjusted to $\mathrm{pH}$ 5.5. Control seedlings were grown in the nutrient solution alone. The solutions were continuously aerated with an aquarium air pump every day.

\section{Determination of $\mathrm{Cd}$ and other Minerals}

Both control plants and plants exposed to $50 \mu \mathrm{M}$ of $\mathrm{Cd}$ for $1,3,6,12$, and 24 hours were harvested based on uniformity of size and colour (removing the greatest and the smallest plants, followed by random selection). The roots for each treatment were washed thoroughly with running tap water for 30 minutes, incubated for 10 minutes in $20 \mathrm{mM}$ of disodium ethylenediamine tetraacetic acid $\left(\mathrm{Na}_{2}\right.$-EDTA) at room temperature, and then washed with deionized water to remove traces of nutrients and $\mathrm{Cd}$ ions from their surfaces. The roots were dried at $45^{\circ} \mathrm{C}$ for 72 hours, $80^{\circ} \mathrm{C}$ for 24 hours, and $105^{\circ} \mathrm{C}$ for 12 hours. After weighing, dried-root material $(0.2 \mathrm{~g})$ was digested with a mixture of $\mathrm{HNO}_{3}$ and $\mathrm{HClO}_{4}(4: 1, \mathrm{v} / \mathrm{v})$ at a controlled temperature of $160^{\circ} \mathrm{C}$; the ratio of the volume $(\mathrm{mL})$ of the mixture acid/mass to the tissue $(\mathrm{g})$ was 20:1. After dry-ashing, concentrations of $\mathrm{Cd}, \mathrm{Mn}, \mathrm{Zn}, \mathrm{Ca}$, and $\mathrm{Fe}$ were analyzed using inductively coupled plasma atomic emission spectrometry (ICP-AES, Leeman Labs Inc., USA).

\section{Total RNA Extraction and First-Strand cDNA Synthesis}

Roots of control and treatment groups exposed to $50 \mu \mathrm{M}$ of $\mathrm{Cd}$ for $1,3,6,12$, and 24 hours were used for gene expression analysis. They were separated and washed with deionized water. Total RNA was extracted using the easyspin Plant RNA Extraction Kit (Aidlab, China), and FirstStrand Synthesis SuperMix (TransScript, China) was used for cDNA synthesis - both according to the manufacturers' instructions. RNA integrity was verified by running agarose gel electrophoresis and detecting the three bands corresponding to ribosomal RNA 25S, $18 \mathrm{~S}$, and 5S. Total extracted RNA was quantified with a NanoDrop $200^{\circ} \mathrm{C}$ Spectrophotometer (Biochrom, England) and stored at $-80^{\circ} \mathrm{C}$. Each treatment was replicated twice.

\section{Quantitative Real-Time Reverse Transcription-PCR (qRT-PCR)}

Roots of control and treatment groups exposed to $50 \mu \mathrm{M}$ of $\mathrm{Cd}$ for 1, 3, 6, 12, and 24 hours were used. Every cDNA template for the qRT-PCR reaction with 7500 RealTime PCR (Applied Biosystems, USA) was measured using a SYBR Select Master Mix (Applied Biosystems, USA). The programme used for qRT-PCR was as follows: UDG activation at $50^{\circ} \mathrm{C}$ for 2 minutes, Amplitaq fast DNA polymerase, up activation at $95^{\circ} \mathrm{C}$ for 2 minutes, followed by 40 cycles of denaturation at $95^{\circ} \mathrm{C}$ for 15 seconds and annealing/extension at $50^{\circ} \mathrm{C}$ for one minute. The gene-specific forward and reverse primers and cDNA 
Table 1. Sequences of primers for qRT-PCR.

\begin{tabular}{|c|c|c|}
\hline Target & Primer sequences (5' '3') & GenBank accession No. \\
\hline \multirow{2}{*}{ PtActin } & $\begin{array}{r}\text { F: CCCCTCAACGCTAAGGCTAACAG } \\
\text { R: CAGAATCTTCATCAAAGCATCGGTG }\end{array}$ & XM_002298674.2 \\
\hline \multirow{2}{*}{ PeIRT1 } & $\begin{array}{l}\text { F: TTTACACGTTCGATCCCTGCTT } \\
\text { R: CTGATAACATAGCTCCAAACCC }\end{array}$ & XM_011042073.1 \\
\hline PtNRAMP1 & $\begin{array}{l}\text { F: GCAGAACACTGTAGGAATGA } \\
\text { R: GCAGAACACTGTAGGAATGA }\end{array}$ & XM_006368452.1 \\
\hline PtZIP1 & $\begin{array}{l}\text { F: TGAAATACAAAGCCGCAGCAAT } \\
\text { R: TCGGGAAGCACATGAATAAAGG }\end{array}$ & XM_002307824.2 \\
\hline
\end{tabular}

Note: 'F' was defined as forward primer and ' $R$ ' as reverse primer.

template were added to the SYBR Select Master Mix. Primers for the genes were designed by Primer 5.0 with gene sequences from GenBank in NCBI. The Populus trichocarpa actin gene was used as a reference for all genes. Primers designed for the target genes and reference gene are detailed in Table 1. Real-time PCR experiments were conducted on the two biological replicates, with three technical replicates for each sample. Melting curves were used to assess amplification specificity. The relative quantities of the transcripts were analyzed using the comparative $\mathrm{Ct}$ method [24].

\section{Statistical Analysis}

Data from this investigation were analyzed with Sigma Plot 13.0 using means \pm standard error (SE). For equality of averages, a t-test was applied. Results were considered statistically significant at $P<0.05$.

\section{Results}

Cd Accumulation and its Effects on Other Minerals

Statistical analysis from inductively coupled plasma atomic emission spectrometry (ICP-AES) showed significant correlations between concentrations of $\mathrm{Cd}$ and microelements ( $\mathrm{Fe}, \mathrm{Mn}, \mathrm{Ca}$, and $\mathrm{Zn}$ ). The level of $\mathrm{Cd}$ in roots increased significantly $(P<0.05)$ with prolonged treatment times when compared with control (Table 2). The roots of $S$. matsudana exposed to $50 \mu \mathrm{M}$ of $\mathrm{Cd}$ for 1 , $3,6,12$, and 24 hours rapidly absorbed and accumulated large amounts of Cd: approximately 280, 587, 605, 622, and $795 \mu \mathrm{g} / \mathrm{g}$ (DW), respectively. Concentrations of Mn, $\mathrm{Fe}, \mathrm{Ca}$, and $\mathrm{Zn}$ in roots decreased $(P<0.05)$ in the presence of $\mathrm{Cd}$ (Table 2) when compared to control, except for $\mathrm{Zn}$ at six hours. After 24 hours of treatment, Cd stress caused a decrease of $\mathrm{Fe}(34.1 \%), \mathrm{Mn}(60.1 \%), \mathrm{Zn}(40.7 \%)$, and $\mathrm{Ca}(26.5 \%)$.

\section{Expression of IRT1, NRAMP1, and ZIP1 Genes}

In order to elucidate the different durations of $\mathrm{Cd}$ uptake at the genetic level, changes in relative expressions of IRT1, NRAMP1, and ZIP1 genes in the roots of $S$. matsudana exposed to $50 \mu \mathrm{M}$ of $\mathrm{Cd}$ from 1 hour to 24 hours were examined. The expression of IRT1 in roots was higher than in control $(P<0.05)$ during the whole $\mathrm{Cd}$ treatment period (Fig. 1). After 24 hours of exposure, the relative expression of IRT1 peaked: an increase 6.7 times higher than that of control treatment $(P<0.05)$. With regard to NRAMP1, relative expression in the roots varied according to the duration of treatment. A sharp increase of $160.8 \%$ for the relative expression of

Table 2. Concentrations ( $\mu \mathrm{g} / \mathrm{g} \mathrm{DW}$ ) of $\mathrm{Cd}, \mathrm{Fe}, \mathrm{Mn}, \mathrm{Zn}$, and $\mathrm{Ca}$ in roots of S. matsudana exposed to $50 \mu \mathrm{M} \mathrm{Cd}$ for different treatment times.

\begin{tabular}{|c|c|c|c|c|c|c|}
\hline \multirow{2}{*}{ Element } & \multicolumn{7}{|c|}{$\mu \mathrm{g} \mathrm{g}^{-1}$ dry weight \pm standard error } \\
\cline { 2 - 7 } & $0 \mathrm{~h}$ & $1 \mathrm{~h}$ & $3 \mathrm{~h}$ & $6 \mathrm{~h}$ & $12 \mathrm{~h}$ & $24 \mathrm{~h}$ \\
\hline $\mathrm{Cd}$ & $0.00 \pm 0.00 \mathrm{a}$ & $280.53 \pm 0.84 \mathrm{~b}$ & $587.38 \pm 4.25 \mathrm{c}$ & $605.51 \pm 2.11 \mathrm{~d}$ & $622.95 \pm 5.05 \mathrm{e}$ & $795.58 \pm 1.00 \mathrm{f}$ \\
\hline $\mathrm{Fe}$ & $730.18 \pm 4.02 \mathrm{a}$ & $701.03 \pm 3.57 \mathrm{~b}$ & $612.73 \pm 2.97 \mathrm{c}$ & $614.94 \pm 1.71 \mathrm{c}$ & $531.51 \pm 2.30 \mathrm{~d}$ & $481.14 \pm 0.84 \mathrm{e}$ \\
\hline $\mathrm{Mn}$ & $547.56 \pm 0.96 \mathrm{a}$ & $498.70 \pm 6.13 \mathrm{~b}$ & $507.85 \pm 1.38 \mathrm{~b}$ & $410.95 \pm 2.33 \mathrm{c}$ & $405.07 \pm 1.90 \mathrm{c}$ & $218.70 \pm 1.54 \mathrm{~d}$ \\
\hline $\mathrm{Zn}$ & $590.85 \pm 2.28 \mathrm{a}$ & $490.10 \pm 1.68 \mathrm{~b}$ & $469.59 \pm 7.03 \mathrm{c}$ & $485.84 \pm 5.02 \mathrm{~d}$ & $434.21 \pm 1.21 \mathrm{e}$ & $350.34 \pm 8.96 \mathrm{f}$ \\
\hline $\mathrm{Ca}$ & $5,614.95 \pm 24.49 \mathrm{a}$ & $5,145.33 \pm 30.12 \mathrm{~b}$ & $4,989.86 \pm 22.34 \mathrm{c}$ & $5,046.76 \pm 5.40 \mathrm{c}$ & $4,738.24 \pm 11.93 \mathrm{~d}$ & $4,127.69 \pm 15.59 \mathrm{e}$ \\
\hline
\end{tabular}

Values followed by different letters are significantly different $(P<0.05) . \mathrm{n}=4$. 


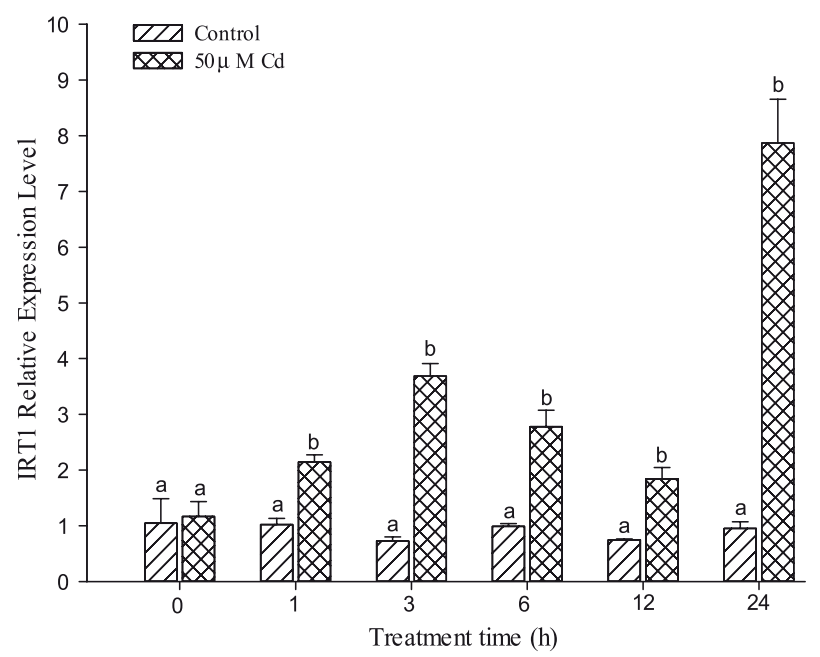

Fig. 1. qRT-PCR analysis of IRT1 expression level in roots of S. matsudana exposed to $50 \mu \mathrm{M} \mathrm{Cd}$ with different treatment times. Values with different letters differ significantly from each other $(\mathrm{n}=3, P<0.05)$. Data are means $\pm \mathrm{SE}$.

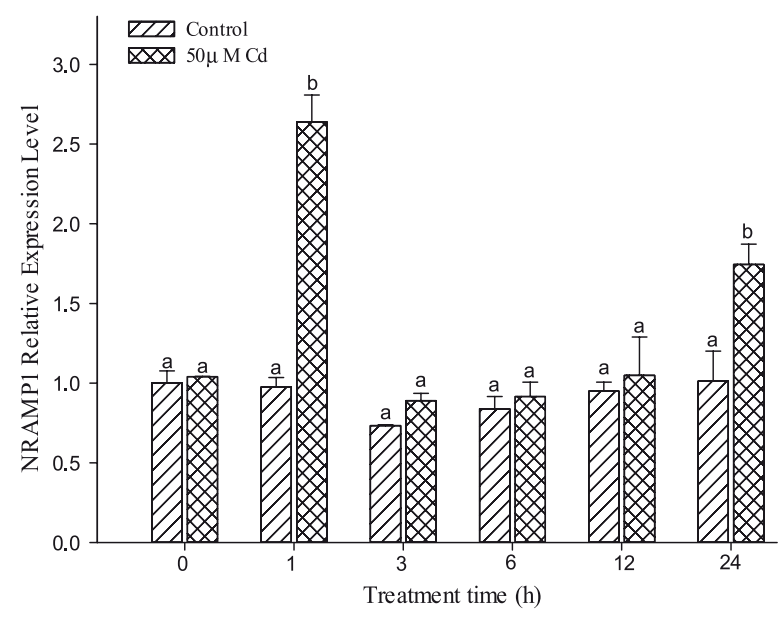

Fig. 2. qRT-PCR analysis of NRAMP1 expression level in roots of $S$. matsudana exposed to $50 \mu \mathrm{M} \mathrm{Cd}$ with different treatment times. Values with different letters differ significantly from each other $(\mathrm{n}=3, P<0.05)$. Data are means $\pm \mathrm{SE}$.

NRAMP1 was detected after exposure to Cd treatment for 1 hour $(P<0.05)$ when compared to control, after which the expression declined (Fig. 2). However, the relative expression of NRAMP1 was again higher $(P<0.05)$ after exposure for 24 hours, increasing by $78.8 \%$. In addition, it is certain that the expression of ZIP1 increased sharply after exposure to $50 \mu \mathrm{M} \mathrm{Cd}$ for one hour, which is 5.9 times that of control treatment $(P<0.05)$ (Fig. 3). After three hours of the stress, the expression of ZIP1 reached a maximum, which is 10 times that of control $(P<0.05)$.

\section{Discussion}

Some heavy metals such as cobalt $(\mathrm{Co})$, copper $(\mathrm{Cu})$, iron $(\mathrm{Fe})$, manganese $(\mathrm{Mn})$, molybdenum $(\mathrm{Mo})$, nickel

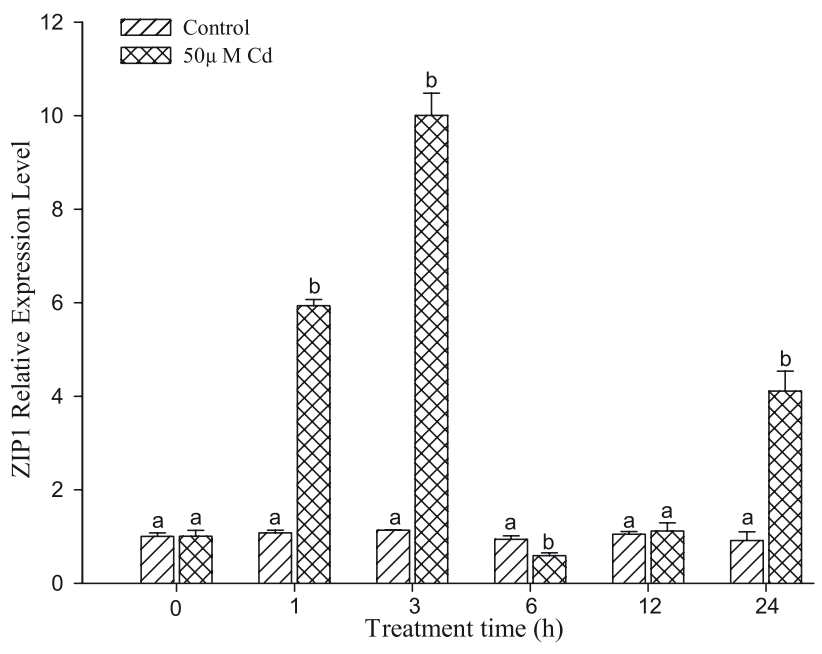

Fig. 3. qRT-PCR analysis of ZIP1 expression level in roots of S. matsudana exposed to $50 \mu \mathrm{M} \mathrm{Cd}$ with different treatment times. Values with different letters differ significantly from each other $(\mathrm{n}=3, P<0.05)$. Data are means $\pm \mathrm{SE}$.

$(\mathrm{Ni})$, and zinc $(\mathrm{Zn})$ are metal micronutrients that play an essential role in plant cell growth and development [25]. Dynamic equilibrium of these heavy metals in plant cells is necessary to avoid deficiency and toxicity [1]. To achieve this, plants utilize some stringent regulatory mechanisms. It is well known that the absorption and maintenance of heavy metal ions in cells are controlled by specific transporters and metal pumps [26]. Cd ion uptake occurs via transmembrane carriers engaged in the uptake of $\mathrm{Ca}, \mathrm{Fe}$, magnesium ( $\mathrm{Mg}), \mathrm{Cu}$, and $\mathrm{Zn}$ [27-28]. At the root level, IRT1, ZIP1, and NRAMP1 are the best-studied non-specific transporters responsible for $\mathrm{Cd}$ uptake and other divalent metal nutrient transporters [29-32].

Some investigations have proven that transporters (including the ZIP family transporters) participate in $\mathrm{Cd}$ absorption and accumulation in plants, and the balance between transport processes [31-33]. IRT1, the earliest discovered member of the ZIP family, is not only the primary root iron uptake system in plants but can also transport significant amounts of Cd [34-35]. In the present investigation, the relative expression of IRT1 in the roots of $S$. matsudana exposed to $50 \mu \mathrm{M}$ of $\mathrm{Cd}$ during the whole treatment period increased significantly $(P<0.05)$ and large amounts of $\mathrm{Cd}$ were absorbed, suggesting that IRT1 plays an important role in Cd uptake. ZIP1 belong to the same transporter family with IRT1. ZIP1, ZIP3, ZIP4, ZIP5, ZIP9, and ZIP10 genes in Arabis thaliana have been demonstrated to be an important factor to control $\mathrm{Zn}$ uptake, as they encode a plasma membrane-localized Zn-specific transporter. [36-38]. The current studies have shown $\mathrm{Cd}$ transport in rice, tomato, tobacco, and radish by ZIP1 [16, 32, 39-40]. In the present investigation, expression of ZIP1 increased significantly and quickly in the roots of $S$. matsudana for the early stage of $50 \mu \mathrm{M} \mathrm{Cd}$ treatments (Fig. 3), suggesting that ZIP1 may play crucial roles in the early absorption of Cd. NRAMP1 can be considered a kind of 
$\mathrm{Fe}$ transporter in plants, and its expression can be induced by $\mathrm{Fe}$ deficiency in roots [19]. Cailliatte et al. [18] demonstrated that the metal transporter NRAMP1 was high-affinity Mn uptake that is essential for growth in conditions of low $\mathrm{Mn}$ availability. The results from Xiao et al. [30] and Thomine et al. [21] also showed that NRAMP1 encodes a functional metal transporter responsible for mediating the distribution of ions as well as the transportation of $\mathrm{Cd}$ in plants. In these studies, the increased relative expression of IRT1, ZIP1, and NRAMP1 in Cd-treated roots led to increased Cd uptake. IRT1 and ZIP1 plays a dominant role in the absorption of Cd compared with NRAMP1 in $S$. matsudana's early exposure to $\mathrm{Cd}$. Meanwhile, the relative expression of IRT1 and NRAMP1 is likely stimulated by Cd-induced $\mathrm{Fe}, \mathrm{Zn}$, and/or Mn deficiency.

Different concentrations of Cd may lead to different expressions of these genes. It was reported that IRT1, Nramp1, and ZIP1 expression increased in two tomato genotypes with increases in the Cd concentration [32]. The results from other studies showed that high $\mathrm{Cd}$ accumulators had high expression of IRT1 and ZIP1 when in comparison with low $\mathrm{Cd}$ accumulators [32, 35, 41]. More studies, however, are required in this direction.

Evidence has confirmed that adding excessive $\mathrm{Fe}$ and $\mathrm{Mn}$ to a solution containing $\mathrm{Cd}$ can reduce $\mathrm{Cd}$ uptake, ameliorate phytotoxicity, and alleviate (to some extent) Cd-induced inhibitory effects on growth parameters of kidney bean seedlings, maize plants, and rice by preventing impairment in pigment synthesis [42]. Choppala et al. [1] found that $\mathrm{Fe}$ and $\mathrm{Mn}$ were conducive to internal defensive mechanisms in plants. They compete with $\mathrm{Cd}$ in the active transporters and can minimize $\mathrm{Cd}$ transportation into plants. Here, the contents of $\mathrm{Fe}, \mathrm{Mn}$, and $\mathrm{Cd}$ levels in the roots showed a negative correlation during the whole experiment, which may explain why concentrations of $\mathrm{Fe}$ and $\mathrm{Mn}$ gradually declined with increased $\mathrm{Cd}$ concentrations in the roots (Table 2). Chemical similarities and interactions between $\mathrm{Zn}$ and $\mathrm{Cd}$ are thought to be the main causes of $\mathrm{Cd}$ toxicity in higher plants. $\mathrm{Cd}$ and $\mathrm{Zn}$ belong to Group IIB in the periodic table and form tetrahedral complexes, competing for the same binding sites and/or ligands in biological systems [43]. $\mathrm{Zn}$ is known as a cofactor in many enzymes and regulatory protein. Interference by $\mathrm{Cd}$ in $\mathrm{Zn}$ homeostasis may result in serious effects on cell growth, development, and functioning [42]. $\mathrm{Zn}$ and Cd likely pass into the cell membrane through transporter protein family members by ZIP (zinc-regulated transporter-like proteins or ironregulated transporter-like proteins) [44]. Other studies have reported that $\mathrm{Cd}$ ions could enter root cells via orthologues of AtIRT1, TcZNT1/TcZIP4, and TaLCT1, or via cation channels [7, 45-46]. The results of the present investigation have shown that the concentration of $\mathrm{Zn}$ in the roots of $S$. matsudana decreased $(P<0.05)$ during the whole experiment, except for the treatment group exposed to $50 \mu \mathrm{M}$ of $\mathrm{Cd}$ for six hours, which is consistent with previous investigations where $\mathrm{Cd}$ induced a marked reduction of $\mathrm{Zn}$ levels in Allium cepa [47] and maize
[48]. Cd and Ca have similar ionic radii $(0.099 \mathrm{~nm}$ and $0.097 \mathrm{~nm}$, respectively) and compete for the same $\mathrm{Ca}$ channels in plants [49]. Shortly after Cd enters the cytoplasm, it binds to certain sites in the root tip apoplast, affecting the function of the plasmalemma pumps transporting $\mathrm{Ca}$ ions and resulting in the interference of Ca uptake.

\section{Acknowledgements}

This project was supported by the National Natural Science Foundation of China. The authors wish to express their appreciation to the reviewers for this paper.

\section{References}

1. CHOPPALA G., SAIFULLAH, BOLAN N., BIBI S., IQBAL M., RENGEL Z., KUNHIKRISHNAN A., ASHWATH N., SIK OK Y. Cellular mechanisms in higher plants governing Tolerance to Cadmium Toxicity. Crit. Rev. Plant Sci. 33, 374, 2014.

2. MONTEIRO C.C., CARVALHO R.F., GRATAO P.L., CARVALHO G., TEZOTTO T., MEDICI L.O., PERES L.E.P., AZEVEDO R.A. Biochemical responses of the ethylene-insensitive Never ripe tomato mutant subjected to cadmium and sodium stresses. Environ. Experi. Bot. 71, 306, 2011.

3. TOMAR P.C., LAKRA N., MISHRA S.N. Effect of cadaverine on Brassica juncea (L.) under multiple stress. Indian J. Experi. Biol. 51, 758, 2013.

4. GAO F. The mystery of heavy metal pollution in farmland. China Land. 2, 14, 2014.

5. CUI S., ZHOU Q., CHAO L. Potential hyperaccumulation of $\mathrm{Pb}, \mathrm{Zn}, \mathrm{Cu}$ and $\mathrm{Cd}$ in endurant plants distributed in an old smeltery, northeast China. Environ. Geol. 51, 1043, 2007.

6. BI X.Y., FENG X.B., YANG Y.G., LI X.D., SHIN G.P.Y., LI F., QIU G.L., LI G.H., LIU T.Z., FU ZH.Y. Allocation and source attribution of lead and cadmium in maize (Zea mays L.) impacted by smelting emissions. Environ. Pollut. 157, 834, 2009.

7. VERBRUGGEN N., HERMANS C., SCHAT H. Molecular mechanisms of metal hyeraccumulation in plants. New Phytol. 181, 759, 2009.

8. HASSAN Z., AARTS M.G.M. Opportunities and feasibilities for biotechnological improvement of $\mathrm{Zn}, \mathrm{Cd}$ or Ni tolerance and accumulation in plants. Environ. Experi. Bot. 72, 53, 2011.

9. NA G., SALT D.E. The role of sulfur assimilation and sulfur-containing compounds in trace element homeostasis in plants. Environ. Experi. Bot. 72, 18, 2011.

10. RASCIO N., NAVARI-IZZO F. Heavy metal hyperaccumulating plants: How and why do they do it? And what makes them so interesting? Plant Sci. 180, 169, 2011.

11. PENCE N.S., LARSEN P.B., EBBS S.D., LETHAM D.L.D., LASAT M.M., GARVIN D.F., EIDE D., KOCHIAN L.V. The molecular physiology of heavy metal transport in the $\mathrm{Zn} / \mathrm{Cd}$ hyperaccumulator Thlaspi caerulescens. Proc. Natl. Acad. Sci. USA. 97, 4956, 2000.

12. SASAKI A., YAMAJI N., YOKOSHO K., MA J.F. Nramp5 is a major transporter responsible for manganese and cadmium uptake in rice. Plant Cell. 24, 2155, 2012. 
13. PARK W., AHN S.J. How do heavy metal ATPases contribute to hyperaccumulation? J. Plant Nutr. Soil Sci. 177, 121, 2014

14. BARBERON M., DUBEAUX G., KOLB C., ISONO E., ZELAZNY E., VERT G. Polarization of iron-regulated transporter 1 (IRT1) to the plant-soil interface plays crucial role in metal homeostasis. P. Natl. Acad. Sci. USA. 111, 8293, 2014.

15. RAMESH S.A., SHIN R., EIDE D.J., SCHACHTMAN D.P. Differential metal selectivity and gene expression of two zinc transporters from rice. Plant Physiol. 133, 126, 2003.

16. XU X.Y., DING Z.J., CHEN L., YAN J.Y., LI G.X., ZHENG S.J. An eukaryotic translation initiation factor, AteIF_5A-2, affects cadmium accumulation and sensitivity in Arabidopsis. J. Integr. Plant Boil. 57, 848, 2015.

17. CAILLIATTE R., SCHIKORA A., BRIAT J.F., MARI S., CURIE C. High-affinity manganese uptake by the metal transporter NRAMP1 is essential for Arabidopsis growth in low manganese conditions. Plant Cell. 22, 904, 2010.

18. CURIE C., ALONSO J.M., JEAN M.L., ECKER J.R., BRIAT J.F. Involvement of NRAMP1 from Arabidopsis thaliana in iron transport. J. Biochem. 347, 749, 2000.

19. TAKAHASHI R., ISHIMARU Y., SENOURA T., SHIMO H., ISHIKAWA S., ARAO T., Nakanishi H, Nishizawa N.K. The OsNRAMP1 iron transporter is involved in $\mathrm{Cd}$ accumulation in rice. J. Exp. Bot. 62, 4843, 2011.

20. CAILLIATTE R., LAPEYRE B., BRIAT J.F., MARI S., CURIE, C. The NRAMP6 metal transporter contributes to cadmium toxicity. J. Biochem. 422, 217, 2009.

21. THOMINE S., WANG R., WARD J.M., CRAWFORD N.M., SCHROEDER J.I. Cadmium and iron transport by members of a plant metal transporters family in Arabidopsis with homology to NRAMP genes. Proc. Natl. Acad. Sci. USA. 97, 4991, 2000.

22. UENO D., MILNER M., YAMAJI N., YOKOSHO K., KOYAMA E., ZAMBRANO M.C., KASKIE M., EBBS S., KOCHIAN L.V., MA J.F. Elevated expression of TcHMA3 plays a key role in the extreme $\mathrm{Cd}$ tolerance in a $\mathrm{Cd}$ hyperaccumulating ecotype of Thlaspi caerulescens. Plant J. 66, 852, 2011.

23. JIANG Z., QIN R., ZHANG H.H., ZOU J.H., SHI Q.Y., WANG J.R., JIANG W.S., LIU D.H. Determination of $\mathrm{Pb}$ genotoxic effects in Allium cepa root cells by fluorescent probe, microtubular immunofluorescence and comet assay. Plant Soil 383, 357, 2014.

24. LIVAK K.J., SCHMITTGEN T.D. Analysis of relative gene expression data using real-time quantitative PCR and the 2 (-Delta Delta C(T)) method. Methods 25, 402, 2001

25. HANSCH R., MENDEL R.R. Physiological functions of mineral micronutrients $(\mathrm{Cu}, \mathrm{Zn}, \mathrm{Mn}, \mathrm{Fe}, \mathrm{Ni}, \mathrm{Mo}, \mathrm{B}, \mathrm{Cl})$. Curr. Opin. Plant Biol. 12, 259, 2009.

26. PILON M., COHU C.M., RAVET K., ABDEL-GHANY S.E., GAYMARD F. Essential transition metal homeostasis in plants. Curr. Opin. Plant Biol. 12, 3472009.

27. ROTH U., VON ROEPENACK-LAHAYE E., CLEMENS $\mathrm{S}$. Proteome changes in Arabidopsis thaliana roots upon exposure to $\mathrm{Cd}^{2+}$. J. Experi. Bot. 57, 4003, 2006.

28. CLEMENS S. Toxic metal accumulation, responses to exposure and mechanisms of tolerance in plants. Biochimie. 88, 1707, 2006

29. LIN Y.F., ARTS M.G.M. The molecular mechanism of zinc and cadmium stress response in plants. Cell Mol. Life Sci. 69, 3187, 2012.

30. XIAO H.H., YIN L.P., XU X.F., LI T.Z., HAN Z.H. The iron-regulated transporter, MbNRAMP1, isolated from Malus baccata is involved in $\mathrm{Fe}, \mathrm{Mn}$ and Cd trafficking. Ann.
Bot. 102, 881, 2008.

31. CHAFFAI R., KOYAMA H. Chapter 1-Heavy Metal Tolerance in Arabidopsis thaliana. Adv. Bot. Res. 60, 1, 2011.

32. ZHAO S.P., ZHANG Y.Z., YE X.Z., ZHANG Q., XIAO W.D. Responses to cadmium stress in two tomato genotypes differing in heavy metal accumulation. Turk. J. Bot. 39, 615, 2015.

33. LUX A., MARTINKA M., VACULIK M., WHITE P.J. Root responses to cadmium in the rhizosphere. J. Experi. Bot. 62, 21, 2011.

34. RAMESH S.A., SHIN R., EIDE D.J., SCHACHTMAN D.P. Differential metal selectivity and gene expression of two zinc transporters from rice. Plant Physiol. 133, 126, 2003.

35. WU Z.C., ZHAO X.H., SUN X.C., TAN Q.L., TANG Y.F., NIE Z.J., HU C.X. Xylem transport and gene expression play decisive roles in cadmium accumulation in shoots of two oilseed rape cultivars (Brassica napus). Chemosphere 119, 17, 2015.

36. VAN DE MORTEL J.E., VILLANUEVA L.A., SCHAT H., KWEKKEBOOM J., COUGHLAN S., MOERLAND P.D., VAN THEMAAT E.V.L, KOORNNEEF M., AARTS M.G.M. Large expression differences in genes for iron and zinc homeostasis, stress response, and lignin biosynthesis distinguish roots of Arabidopsis thaliana and the related metal hyperaccumulator Thlaspi caerulescens. Plant Physiol. 142, 1127, 2006.

37. TALKE I.N., HANIKENNE M., KRAMER U. Zincdependent global transcriptional control, transcriptional deregulation, and higher gene copy number for genes in metal homeostasis of the hyperaccumulator Arabidopsis halleri. Plant Physiol. 16, 1, 2006.

38. ASSUNÇÃO A.G.L., HERRERO E., LIN Y.F., HUETTEL B., TALUKDAR S., SMACZNIAK C., IMMINK R.G.H., VAN ELDIK M., FIERS M., SCHAT H. Arabidopsis thaliana transcription factors bZIP19 and bZIP23 regulate the adaptation to zinc deficiency. Proc. Nat. Acad. Sci. 107, 10296, 2010.

39. SHIMO H., ISHIMARU Y., AN G., YAMAKAWA T., NAKANISHI H., NISHIZAWA N.K. Low cadmium (LCD), a novel gene related to cadmium tolerance and accumulation in rice, J. Experi. Bot. 62, 5727, 2011.

40. GONG Y.Q., LIU L.W. De novo sequencing of root transcriptome reveals complex cadmium-responsive regulatory networks in radish (Raphanus sativus L.). Plant Sci. 236, 313, 2015.

41. ROGERS E.E., EIDE D.J., GUERINOT M.L. Altered selectivity in an Arabidopsis metal transporter. P. Natl. Acad. Sci., 12356, 2000.

42. SHAO G.S., CHEN M.X., WANG D.Y., XU CH.M., MOU R.X., CAO ZH.Y., ZHANG X.F. Using iron fertilizer to control $\mathrm{Cd}$ accumulation in rice plants: A new promising technology. Sci. China Life Sci. 51, 245, 2008.

43. MATOVIĆ V., BUHA A., BULAT Z., ĐUKIĆ-ĆOSIĆ D. Cadmium toxicity revisited: Focus on oxidative stress induction and Interactions with zinc and magnesium. Arh. Hig. Rada Toksikol. 62, 65, 2011.

44. GUERINOT M.L. The ZIP family of metal transporters. Biochim. Biophys. Acta. 1465, 190, 2000.

45. DAL CORSO G., FARINATI S., MAISTRI S., FURINI A. How plants cope with cadmium: Staking all on metabolism and gene expression. J. Int. Plant Biol. 50, 1268, 2008.

46. PEDAS P., YTTING C.K., FUGLSANG A.T., JAHN T.P., SCHJOERRING J.K., HUSTED S. Manganese efficiency in barley: identification and characterization of the metal ion transporter HvIRT1. Plant Physiol. 148, 455, 2008. 
47. ZOU J.H., YUE J.Y., ZHANG Z.G., JIANG W.S, LIU D.H. Effects of cadmium stress on root tip cells and some physiological indexes in Allium cepa var. agrogarum L. Acta. Biol. Cracov. Bot. 54, 129, 2012.

48. WANG M., ZOU J.H., DUAN X.C., JIANG W.S., LIU D.H.
Cadmium accumulation and its effects on metal uptake in maize (Zea mays L.). Bioresource Tech. 98, 82, 2007.

49. NELSON M.T. Interactions of divalent cations with single calcium channels from rat brain synaptosomes. J. Gen. Physiol. 87, 986, 2011. 